\title{
Profil Berpikir Metaforis (Metaphorical Thinking) Siswa SMP dalam Memecahkan Masalah Pengukuran Ditinjau dari Gaya Kognitif
}

\author{
'Windi Setiawan \\ 'Program Pascasarjana Pendidikan Matematika Universitas Negeri Surabaya \\ Email: windi.setiawan1408@yahoo.com
}

DOI: http://dx.doi.org/10.15294/kreano.v7i2.7127

Rec eived: August, 2016; Accepted: November, 2016; Published: December, 2016

\begin{abstract}
Abstrak
Penelitian yang dilakukan merupakan penelitian deskriptif dengan pendekatan kualitatif yang bertujuan untuk mendeskripsikan profil berpikir metaforis siswa SMP dalam memecahkan masalah pengukuran ditinjau dari gaya kognitif. Subjek penelitian ini adalah dua siswa yang terdiri atas siswa bergaya kogntif reflektif (SR) dan siswa bergaya konitif impulsif (SI). Pengumpulan data dilakukan dengan pemberian tugas pemecahan masalah dan wawancara semi terstruktur. Triangulasi waktu digunakan untuk menguji kredibilitas data. Hasil penelitian ini adalah deskripsi berpikir metaforis yang terdiri atas connect, relate, explore, analyze, transform dan experience.
\end{abstract}

\begin{abstract}
Metaphorical thinking is the mental activity by using metaphors that fit the situation. Metaphor is an idea to link the problems faced by everyday experience and the familiar mathematical material. This research is descriptive research with qualitative approach that aimed to describe the metaphorical think profile of junior high school students for solving measurement problem based on cognitive style. The subjects of this research are two students consist of a student with cognitive style (SR) and a student with cognitive impulsive style (SI). The data collecting technique that used in this research is by giving the assignment of problem solving and semi-structured interviews. Triangulation of time used to test the credibility of the data out of this research. The result of this study is description of metaphorical thinking consists of connect, relate, explore, analyze, transform and experience.
\end{abstract}

Keywords: metaphorical thinking; measurement problem; cognitive style

\section{PENDAHULUAN}

Matematika merupakan mata pelajaran yang dipelajari di setiap jenjang pendidikan mulai dari SD, SMP, SMA sampai jenjang perguruan tinggi. Selain itu matematika sangat membantu dan dibutuhkan pada bidang studi atau ilmu-ilmu yang lain. Kurikulum 2013 (dalam Hendriana, 2014) telah menetapkan tujuan pembelajaran matematika yaitu salah satu di antaranya adalah pemecahan masalah. NCTM (2012) juga menetapkan lima standar proses dalam matematika yaitu problem solving (pemecahan masalah), reasoning and proof (penalaran dan pembuktian), communication (komunikasi), connection (koneksi), dan representation (representasi).

Berdasarkan uraian tersebut, jelas ter- lihat bahwa pemecahan masalah menjadi salah satu prioritas penting dalam matematika. Nasution (2012) menyatakan bahwa pemecahan masalah memerlukan bermacam-macam ketrampilan berpikir seperti melaporkan, mendeskripsi, menganalisis, mengklasifikasi, menafsirkan, mengkritik, meramalkan, dan menarik kesimpulan dan membuat generalisasi berdasarkan informasi yang diperoleh. Pada kenyataannya, tak banyak guru yang sadar akan kompleksitas pemecahan masalah dan memberikan waktu yang cukup untuk membekali siswanya dengan ketrampilan dasar pemecahan masalah. Masih banyak guru yang beranggapan bahwa siswa dengan sendirinya sanggup memiliki kemampuan memecahkan masalah yang bisa digunakan 
dalam setiap pelajaran.

Pemecahan masalah di dalam mata pelajaran matematika bisa dijumpai dalam materi pengukuran. Pengukuran di SMP kerapkali disandingkan dengan materi geometri. Geometri adalah salah satu cabang dari matematika. Susanah (2014) mengutarakan bahwa geometri adalah salah satu cabang matematika yang mempelajari hubungan antara titiktitik, garis-garis, sudut-sudut, bidang-bidang serta bangun ruang. Pengukuran memberikan aplikasi yang praktis bagi siswa untuk ketrampilan berhitung yang mereka pelajari. Di Sekolah Dasar, Pengukuran memiliki ruang lingkup tentang kegiatan mengukur sudut, panjang, luas, dan volume (Yuwono, 2009). Hal ini juga bisa kita jumpai di SMP, materi pengukuran juga meliputi beberapa hal seperti menentukan besar sudut, menentukan luas dan keliling bangun datar, serta menentukan volume dan luas permukaan bangun ruang.

Masalah pengukuran adalah suatu masalah yang disajikan dalam bentuk soal pada materi geometri dan pengukuran yang meliput beberapa sub bab seperti volume, luas, keliling, luas permukaan. Soal tersebut merupakan masalah bila soal itu menunjukkan adanya tantangan yang tidak dapat dipecahkan oleh suatu prosedur rutin yang telah diketahui siswa. Untuk menyelesaikan soal tersebut diperlukan analisis dan tahapan-tahapan dalam menyelesaikannya.

Secara tidak sadar, banyak siswa yang telah berpikir metaforis dalam memecahkan masalah pengukuran. Metaphorical thinking (Sunito, 2013) adalah aktivitas mental untuk menghubungkan dua subjek atau hal yang mungkin bagi orang lain dianggap tidak ada hubungannya, sehingga tidak semua orang dapat melakukannya. Metaphorical thinking dalam memecahkan masalah pengukuran dapat dijumpai dalam penelitian Ferara (2003) yang berhasil menunjukkan aktivitas mental siswa dalam menghubungkan dua hal yang berbeda. Seperti perubahan keliling persegi yang dinyatakan dalam bentuk rumus fungsi. Selain itu, Ferara juga mengungkapkan adanya metafora yang ditemukan berupa pergerakan jari telunjuk siswa ketika memecahkan masalah. Dalam pembelajaran, guru juga sering berpikir metaforis dalam menyampai- kan materi di kelas. Lai (2013), dalam penelitiannya telah menggunakan metafora guna untuk mengembangkan pemahaman siswa tentang makna kesebangunan dan keliling.

Dalam berpikir metaforis, tidak semua individu dapat berpikir metaforis secara maksimal. Hal ini dipengaruhi oleh salah satu faktor salah satunya adalah gaya kognitif. Susanto (2008) mengutarakan bahwa proses berpikir seseorang dipengaruhi oleh karakteristik yang dimiliki oleh setiap individu. Salah satu karakteristik itu adalah gaya kognitif. Sehingga hal ini membuat peneliti menduga, bahwa berpikir metaforis dipengaruh oleh gaya kognitif. Dalam psikologi pendidikan, siswa yang menyelesaikan masalah tanpa pikir panjang memiliki gaya kognitif impulsif. Sebaliknya, siswa yang membutuhkan waktu lama dalam menyelesaikan masalah yang dihadapinya termasuk siswa yang memiliki gaya kognitif reflektif. Penelitian ini fokus kepada dua macam gaya kognitif yaitu gaya kognitif reflektif dan gaya kognitif impulsif. Dipilihnya dua macam gaya kognitif karena gaya kognitif reflektif dan impulsif cenderung mudah dikenali oleh guru dalam pembelajaran di kelas (Sumitri, 2014).

Peneliti berharap dapat memberikan gambaran mengenai profil berpikir metaforis siswa bergaya kognitif reflektif atau impulsif dalam memecahkan masalah pengukuran. Sehingga, hal ini bisa memberikan kemudahan bagi guru untuk menjelaskan kepada siswa tentang pemecahan masalah dengan menggunakan metafora yang sesuai. Siswa juga lebih mudah memahami langkah pemecahan masalah, karena metafora mengaitkan masalah yang dihadapi dengan hal yang lebih dikenal (familiar). Berdasarkan latar belakang yang telah dipaparkan tersebut, penulis terdorong untuk melakukan penelitian yang lebih spesifik dengan judul "Profil Berpikir Metaforis (Metaphorical Thinking) Siswa SMP dalam Memecahkan Masalah Pengukuran Ditinjau Dari Gaya Kognitif"

\section{Berpikir Metaforis}

Sunito (2013) menyebutkan berpikir metaforis dengan sebutan metaphorming. Metaphorming merupakan aktivitas yang merujuk pada kegiatan mengubah suatu materi dari makna 
satu ke makna yang lain. Metaphorming berasal dari meta yang bermakna trancending melampaui dunia nyata, dan kata phora yang berarti transfer.. Metaphorming memberikan kesempatan bagi setiap individu untuk memiliki ide yang cemerlang. Hendriana (2012) menyatakan bahwa berpikir metaforis adalah proses berpikir dengan menggunakan metafora-metafora untuk memamahami suatu konsep. Bazzini (2001) mengutarakan bahwa metafora bukan hanya ungkapan dalam bahasa melainkan cara berpikir. Metafora adalah bagian mendasar dari berpikir matematis. Metafora merupakan sarana bagi siswa untuk memikirkan matematika ke dalam materi dan aktivitas mental yang telah dikenalnya (Lai, 2013). Sanchez-Ruiz et al (2013) menjelaskan bahwa metafora juga berfungsi sebagai sarana untuk memahami konsep abstrak berdasarkan pengetahuan yang terstruktur atau lebih dikenal. Dalam hal ini pengetahuan yang lebih dikenal adalah pengetahuan telah dimiliki siswa sebelumnya. Metafora didefinisikan sebagai pemindahan hubungan konseptual dari domain tertentu (sumber) ke domain yang lain (target). Hasil pemindahan makna antara dua domain yang berbeda adalah sekumpulan konseptual baru yang terorganisasi. Metafora adalah suatu bentuk penggunaan kata atau kalimat yang bertujuan untuk mewakili suatu konsep tertentu. Metafora berfungsi untuk memahami sesuatu yang abstrak menjadi konkrit atau sebaliknya (Alhaddad, 2012). Berpikir metaforis dimulai dengan membuat model-model yang sesuai dengan situasi yang dihadapi dan dimaknai dengan sudut pandang semantik (ilmu tentang makna kata). Model adalah representasi dari situai yang dihadapi oleh setiap individu mempunyai cirri yang yang sama dengan tiruannya dalam melakukan tugas untuk menyelesaikan suatu masalah. Penggunaan model bertujuan untuk meningkatkan komunikasi dalam menyampaikan makna matematika (Lai, 2013). Model sistem konseptual dapat dinyatakan dalam berbagai representasi media seperti simbol tertulis, bahasa lisan, diagram, dan grafik (Lai, 2013). Carreira (2001) mengungkapkan bahwa model dan metafora memiliki hubungan yang sangat dekat. Setiap model yang terbentuk ada metafora di da- lamnya. Hal ini mengartikan bahwa metafora memiliki peranan penting dalam membuat model. Untuk membuat model matematika dari suatu masalah diperlukan hubungan antara dua domain konseptual. Tetapi untuk mengembangkannya agar memiliki banyak keterkaitan diperlukan adanya metafora. Metafora adalah cara yang dibutuhkan untuk memproyeksikan (memaknai) kesimpulan dari satu domain ke domain yang lain. Oleh karena itu, metafora dapat menjadi elemen dasar dalam membuat model yang diinginkan. Berdasarkan paparan di atas, maka dapat disimpulkan berpikir metaforis (metaphorical thinking) adalah aktivitas mental dengan menggunakan metafora-metafora yang sesuai dengan situasi yang dihadapi. Metafora adalah suatu ide untuk mengaitkan masalah yang dihadapi dengan pengalaman seharihari dan materi matematika yang dikenalnya. Langkah-langkah berpikir metaforis menurut Sunito (2013) ialah sebagai berikut.

\section{Connect}

Pada tahap ini, siswa dapat menghubungkan dua hal atau lebih tentang hal yang berbeda baik benda maupun ide, seperti menghubungkan taman dan pikiran. Siswa dapat bertanya kepada dirinya sendiri, bagaimana pikiran seperti taman? Bagaimana dengan berbagai ukuran, bentuk, warna, tekstur dan harumnya bunga yang terhubung dengan ukuran, bentuk, warna dari ide , pikiran, dan perasaan.

\section{Relate}

Siswa dapat menghubungkan ide yang berbeda dengan hal-hal yang telah diketahui sebelumnya. Hal ini dapat dimulai dengan mengamati kesamaan yang ada pada ide tersebut. Misalnya, apakah taman tersebut terus tumbuh seperti bunga liar atau seperti tanaman yang dibudidayakan? Apakah ide tersebut juga ada suatu solusi atau suatu penemuan?

\section{Explore}

Siswa dapat mendeskripsikan kesamaan antara beberapa ide dan membuat model dari ide tersebut. 


\section{Analyze}

Pada tahap ini siswa dapat mengidentifikasi tentang hal-hal yang telah dipikirkan. Siswa dapat mengupas kembali langkah-langkah yang telah dilakukan pada tahap sebelumnya. Pada tahap ini siswa diibaratkan sepeti mencabuti kelopak bunga mawar.

\section{Transform}

Pada tahap ini, siswa juga dapat mengenali atau menemukan sesuatu berdasarkan tahapan sebelumnya yaitu koneksi, eksplorasi, dan hasil analisis pada tahapan sebelumnya.

\section{Experience}

Pada tahap ini siswa dapat menerapkan gambar, model, atau penemuan siswa sebagai hal yang baru sebanyak mungkin.

Berdasarkan penjelasan di atas, maka pada penelitian ini indikator berpikir metaforis dapat dirumuskan dalam Tabel 1.

Tabel 1. Proses berpikir Metaforis

\begin{tabular}{|c|c|}
\hline Proses & Indikator \\
\hline Connect & $\begin{array}{l}\text { Menghubungkan dua ide (materi) yang } \\
\text { berbeda. }\end{array}$ \\
\hline Relate & $\begin{array}{l}\text { Menghubungkan ide yang berbeda } \\
\text { dengan pengetahuan yang lebih dikenali } \\
\text { siswa }\end{array}$ \\
\hline \multirow[t]{2}{*}{ Explore } & Membuat model \\
\hline & Mendeskripsikan kesamaan kedua ide. \\
\hline Analyze & $\begin{array}{l}\text { Mengupas kembali langkah-langkah } \\
\text { yang telah dilakukan sebelumnya! }\end{array}$ \\
\hline Transform & $\begin{array}{l}\text { Menafsirkan dan menyimpulkan } \\
\text { informasi berdasarkan apa yang sudah } \\
\text { dikerjakan. }\end{array}$ \\
\hline Experience & $\begin{array}{l}\text { Menerapkan hasil yang diperoleh pada } \\
\text { permasalahan yang dihadapi. }\end{array}$ \\
\hline
\end{tabular}

\section{Gaya Kognitif Reflektif dan Impusif}

Gaya kognitif impulsif dan reflektif adalah dua hal yang paling sering diteliti dan merupakan salah satu hal yang memiliki fungsi penting bagi manusia (Matczak, 2000; Sternberg \& Grigorenko, 1997). Deswita (2009) menyatakan bahwa "gaya reflektif dan impulsif menunjukkan tempo kognitif atau kecepatan berpikir". Siswa yang memiliki gaya impulsif cenderung memberikan respon yang cepat. Individu yang memberikan respon secara ce- pat dengan sedikit kesalahan disebut sebagai impulsif sejati. Sebaliknya, individu dengan gaya reflektif cenderung menggunakan lebih banyak waktu dalam merenungkan jawaban yang akan diungkapkan.

Nasution (2008) mengatakan bahwa siswa bergaya kognitif impulsif cenderung menggunakan waktu yang cepat untuk memperoleh keputusan tanpa berpikir panjang. Sebaliknya siswa yang bergaya reflektif memerlukan waktu yang lama untuk memperoleh keputusan atau solusi dari masalah yang dihadapinya. Hal ini dikarenakan siswa reflektif masih mempertimbangkan alternatifalternatif yang ikut berpengaruh terhadap keputusan yang diambilnya. Siswa bergaya kognitif reflektif sangat lamban dan hati-hati dalam merespon tapi cenderung memberikan jawaban yang tepat. Beberapa kemungkinan yang dilakukan siswa reflektif adalah mengingat informasi yang terstruktur, membaca dan memahami dan menginterpretasikan teks, memecahkan masalah dan membuat keputusan. Jika dibandingkan dengan siswa impulsif, siswa reflektif memiliki kemungkinan untuk menentukan tujuan sendiri belajarnya. Santrock (2008) telah membuktikan bahwa di dalam pembelajaran siswa reflektif lebih baik dibandingkan siswa impulsif.

Untuk mengukur gaya kognitif reflektifimpulsif digunakan instrumen yang dikembangkan oleh Kagan yang disebut Matching Familiar Figures Test (MFFT), yang terdiri satu gambar standar dan enam gambar yang serupa, tetapi hanya satu gambar yang sama dengan gambar standar. Variabel yang diamati adalah waktu yang digunakan untuk menjawab dan keakuratan dalam menjawab. Dalam penelitian ini digunakan MFFT yang dikembangkan Warli (2010) yang terdiri dari 13 item dengan 8 variasi gambar, yang digunakan untuk mengukur gaya kognitif reflektif-impulsif. Dalam penelitian ini, siswa reflektif dapat didefinisikan sebagai siwa yang sangat berhatihati dalam merespon sesuatu sehingga cenderung lambat dalam menyelesaikan masalah tetapi jawaban yang dihasilkan cenderung benar atau banyak yang benar. Sedangkan siswa yang impulsif dapat didefinisikan sebagai siswa yang cenderung cepat dalam merespon masalah tetapi jawaban yang dihasilkan cen- 
derung salah atau banyak yang salah. Data yang diperoleh dari penggunaan instrumen MFFT, dicatat meliputi banyak waktu yang digunakan oleh siswa untuk menjawab keseluruhan soal ( $\mathrm{t}$ ) dan banyaknya jawaban salah atau jawaban benar siswa tersebut ( $f$ ).

Penetapan waktu ideal yang digunakan untuk pengerjaan instrumen MFFT didasarkan pada hasil uji instrumen yang dilakukan Warli di 3 SMP yang berbeda. Pada penelitian tersebut waktu yang digunakan untuk menyelesaikan satu butir soal MFFT adalah 1,12 menit. Sehingga, untuk mengerjakan 13 butir soal diperlukan waktu 14,56 menit. Selanjutnya, untuk menggolongkannya, waktu ideal maksimal tersebut dibagi menjadi 2 waktu dan didapatkan waktu yang memisahkan keduanya yaitu 7,28 menit. Dengan demikian, siswa menjawab seluruh butir soal dengan waktu kurang dari 7,28 menit dan jawaban yang diberikan banyak yang salah maka siswa tersebut dapat digolongkan ke dalam siswa impulsif. Sedangkan siswa yang menjawab seluruh butir soal dengan waktu lebih dari 7,28 menit dan jawaban yang diberikan banyak yang benar, maka siswa tersebut dapat digolongkan ke dalam siswa reflektif.

Berdasarkan berbagai pendapat di atas, maka dapat disimpulkan bahwa gaya kognitif reflektif adalah karakteristik individu yang mencerminkan bagaimana individu tersebut menggunakan waktu lebih lama untuk menyelesaikan masalah yang dihadapinya tapi jawaban yang dihasilkan banyak yang benar. Sedangkan gaya kognitif impulsif adalah karakteristik individu yang mencerminkan bagaimana individu tersebut menggunakan waktu lebih cepat dalam menyelesaikan permasalahan yang dihadapinya tetapi jawaban yang dihasilkan banyak yang salah.

\section{METODE PENELITIAN}

Jenis penelitian ini merupakan penelitian deskriptif dengan pendekatan kualitatif. Berdasarkan jenis penelitian tersebut, penelitian ini bertujuan untuk mendeskripsikan profil berpikir metaforis siswa dalam memecahkan masalah pengukuran ditinjau dari gaya kognitif. Data penelitian ini diperoleh dari hasil pekerjaan siswa serta wawancara semi terstruktur dengan tujuan untuk menggali informasi mengenai apa yang dipikirkan dan dilakukan subjek penelitian ketika memecahkan masalah pengukuran.

Subjek penelitian ini adalah siswa kelas VIII SMP. Pemilihan subjek penelitian di-

\section{$\mathrm{TPM}_{1}$}

1. Ruas garis $A C$ yang panjangnya $30 \mathrm{~cm}$. Titik $B$ terletak pada ruas garis AC. Bentuklah persegipanjang ABFG dan EDCB. Perhatikan keliling bangun yang dibentuk dari dua persegipanjang ini. Jika titik $B$ digeser sesuai kehendakmu, bagaimana dengan selisih keliling kedua persegipanjang tersebut?

2. Persegipanjang $A B C D$ memiliki luas 60 $\mathrm{cm} 2$. Perhatikan keliling bangun tersebut. Bagaimana perubahan kelilingnya jika panjang dan lebar persegipanjang ini diperpanjang dari semula?

3. Balok ABCD.EFGH memiliki volume 120 cm3. Perhatikan jumlah panjang semua rusuk balok tersebut. Jika panjang, lebar, dan tinggi balok berubah, bagaimanakah dengan jumlah panjang semua rusuk balok tersebut?
$\mathrm{TPM}_{1}$

1. Ruas garis $A C$ yang panjangnya $30 \mathrm{~cm}$. Titik $B$ terletak pada ruas garis $A C$. Bentuklah persegipanjang ABFG dan EDCB. Perhatikan keliling bangun yang dibentuk dari dua persegipanjang ini. Jika titik $B$ digeser sesuai kehendakmu, bagaimana dengan selisih keliling kedua persegipanjang tersebut?

2. Persegipanjang $A B C D$ memiliki luas 60 $\mathrm{cm} 2$. Perhatikan keliling bangun tersebut. Bagaimana perubahan kelilingnya jika panjang dan lebar persegipanjang ini diperpanjang dari semula?

3. Balok $A B C D$.EFGH memiliki volume 120 cm3. Perhatikan jumlah panjang semua rusuk balok tersebut. Jika panjang, lebar, dan tinggi balok berubah, bagaimanakah dengan jumlah panjang semua rusuk balok tersebut? 
lakukan dengan memberikan tes gaya kognitif kepada semua siswa di kelas yang terpilih. Selanjutnya, akan diberikan tes kemampuan matematika. Tes kemampuan matematika ini bertujuan untuk menentukan satu subjek bergaya kognitif reflektif dan satu subjek bergaya kognitif impulsive memiliki kemampuan yang setara artinya perbedaan nilai tes kemampuan matematika berkisar antara o sampai 5 dalam skala o sampai 100.

Instrumen utama dalam penelitian ini adalah peneliti sendiri. Instrumen pendukung dalam penelitian ini adalah Matching Familiar Figure Test (MFFT), Tes Kemampuan Matematika, Tugas Pemecahan Masalah (TPM), dan Pedoman Wawancara. Hasil wawancara dianalisis menggunakan tiga tahap yaitu reduksi data, penyajian data, dan penarikan kesimpulan.

\section{HASIL DAN PEMBAHASAN}

Kegiatan penelitian dimulai dengan pemberian tes kemampuan matematika pada hari Senin, 23 Mei 2016. Setelah itu, pemberian tes MFFT pada hari Jumat, 27 Mei 2016 di MTs. Miftahul Ulum Kemlagi Mojokerto. Pemberian instrumen ini memiliki tuuan untuk menentukan subjek penelitian yang terdiri atas 1 siswa bergaya kognitif reflektif dan 1 siswa bergaya kognitif impulsive dengan kemampuan yang setara. hasil MFFT untuk 28 siswa adalah 12 siswa memiliki gaya kognitif impulsif, 1 siswa merupakan siswa cepat-akurat, dan 2 siswa merupakan siswa lambat-tidak akurat.

Setelah diperoleh satu subjek penelitian, peneliti memberikan tugas pemecahan masalah, kemudian subjek diberikan waktu untuk mengerjakan TPM tersebut. Selanjutnya, peneliti melakukan wawancara kepada setiap subjek setelah TPM dikerjakan. Wawancara dilakukan berdasarkan pekerjaan subjek untuk menggali informasi lebih mendalam yang mungkin tidak terlihat pada hasil pekerjaan TPM yang diberikan peneliti. Wawancara direkam dengan menggunakan voice recorder dan peneliti mencatat segala aktivitas subjek selama wawancara berlangsung. Pemberian TPM dilakukan sebanyak 2 kali yaitu pada hari Selasa tanggal 31 Mei 2016 dan 7 Juni 2016. Setiap subjek diberi tugas pemecahan masalah dan diwawancarai berdasarkan hasil pe- kerjaannya. Berikut ini TPM yang digunakan.

\section{Profil Berpikir Metaforis Siswa SMP Ber- gaya Kognitif Reflektif Dalam Memecah- kan Masalah Pengukuran}

Berpikir metaforis subjek bergaya kognitif reflektif dimulai dengan tahap connect, pada tahap ini, subjek menghubungkan dua ide yang berbeda. Ide pertama adalah subjek menghitung selisih keliling kedua persegipanjang setelah ia misalkan jarak pergeseran suatu titik pada salah satu sisi persegipanjang, perubahan keliling persegipanjang dengan memisalkan penambahan ukuran panjang dan lebar, serta jumlah panjang semua rusuk balok setelah panjang, lebar, dan tinggi balok diperpanjang seperti pada umumnya. Ide kedua, ketiga hal tersebut dinyatakan dalam bentuk persamaan dalam $x$. Pada tahap relate, subjek menghubungkan ide yang berbeda dengan pengetahuan yang telah dimilikinya. SR menghubungkan dengan beberapa topik matematika. Seperti materi aljabar, PLSV, SPLDV, dan volume. SR menyatakan bahwa ia pernah menjumpai suatu soal dalam materi tersebut yang penyelesaiannya membutuhkan pemisalan subjek yang ada dalam soal dengan $x, y$ dan sebagainya. Sehingga atas dasar itulah subjek memisalkan pergeseran titik B dengan variabel. Pada tahap explore, subjek membuat model yang sesuai dengan tugas pemecahan masalah yang diberikan. Subjek menggambar kedua persegipanjang dengan memisalkan ukuran yang diinginkannya dan menentukan besarnya selisih keliling kedua persegipanjang baik pada saat titik B digeser ke kiri atau ke kanan. subjek juga menggambar persegipanjang dengan ukuran yang sesuai dengan luas persegipanjang tersebut serta mentukan perubahan keliling kedua persegipanjang setelah panjang, lebar, dan tinggi diperpanjang dari ukuran semula. Subjek menggambar balok dengan memisalkan ukuran panjang,lebar, dan tinggi yang sesuai dengan volume balok tersebut. la juga menentukan jumlah panjang semua rusuk balok setelah panjang, lebar, dan tinggi balok berubah ukiurannya. Selain itu, Subjek juga dapat mendeskripsikan kesamaan kedua ide yang ia temukan. Untuk soal nomor 1, kesamaannya adalah sama-sama mencari keliling 
dan menggunakan rumus yang sama pula, untuk soal nomor 2, kesamaannya adalah memiliki gambar yang sama, sama-sama mencari keliling dan dengan menggunakan rumus yang sama pula yaitu $2(p+l)$ dan untuk soal nomor 2, kesamaannya adalah memiliki gambar yang sama, sama-sama mencari jumlah panjang semua rusuk balok dan dengan menggunakan rumus yang sama pula yaitu $4(p+l+t)$. Pada tahap analyze, Subjek mengupas kembali langkah- langkah yang telah dilakukan sebelumnya. Subjek menjelaskan kembali bagaimana ia menggambar persegipanjang dan balok dengan memisalkan ukuran yang tepat sesuai luas atau volume yang tertera pada soaL. Subjek juga menjelaskan secara terperinci, bagaima ia menemukan selisih keliling kedua persegipanjang, perubahan keliling persegipanjang dan jumlah panjang semua rusuk balok yang dapat dinyatakan baik dalam bentuk persamaan atau tidak. Subjek juga telah mendeskripsikan kembali kesamaan kedua ide yang ia temukan seperti hanlya pada tahap explore di atas.

Pada tahap transform, subjek menyimpulkan selisih keliling kedua persegipanjang setelah suatu titik pada salah satu sisi persegipanjang digeser ke kiri atau ke kanan besarnya perubahan keliling persegipanjang, serta jumlah panjang semua rusuk balok setelah panjang, lebar, dan tinggi balok berubah. Pada tahap experience, subjek telah menerapkan hasil yang ia dapatkan untuk menyelesaikan masalah yang ia hadapi. Subjek dapat mensubstitusi jarak pergeseran titik B, penambahan ukuran panjang dan lebar, serta besarnya penambahan atau pengurangan ukuran rusuk balok ke persamaan yang dihasilkannya. Dengan begitu, ia dapat mengetahui selisih keliling kedua persegipanjang, perubahan keliling persegipanjang $A B C D$, dan jumlah panjang semua rusuk balok dengan mudah.

\section{Profil Berpikir Metaforis Siswa SMP Ber- gaya Kognitif Impulsif Dalam Memecah- kan Masalah Pengukuran}

Berpikir metaforis dimulai pada tahap connect, subjek dapat menghubungkan kedua ide yang berbeda. Ide pertama adalah subjek menghitung selisih keliling persegi panjang sebelum titik pada salah satu sisi persegipanjang digeser sesuai keinginannya, perubahan keliling persegipanjang setelah panjang dan lebar diperpanjang dari ukuran semula, serta jumlah panjang semua rusuk balok setelah panjang, lebar, dan tinggi balok diperpanjang seperti pada umumnya. Ide yang kedua ketiga hal tersebut dinyatakan dalam bentuk persamaan. Pada tahap relate, subjek menghubungkan ide yang berbeda (ide kedua) dengan pengetahuan yang dimilikinya seperti materi yang ada di dalam matematika. Misalnya keliling bangun datar, volume, dan luar permukaan. Subjek menyatakan bahwa ia pernah menjumpai suatu sial dalam materi tersebut dengan memisalkan yang ditanyakan dengan $x$. sehingga atas dasar itulah subjek memisalkan pergeseran suatu titik pada salah satu sisi persegipanjang, penambahan ukuran panjang dan lebar, serta penambahan atau pengurangan ukuran rusuk balok dengan $x$. Pada tahap explore, subjek dapat membuat model sesuai perrmasalahan yang dihadapi dan tidak mendeskripsikan kesamaan kedua ide. Subjek menggambar kedua persegipanjang dengan memisalkan ukuran yang diinginkannya dan menentukan besarnya selisih keliling kedua persegipanjang baik pada saat titik B digeser ke kiri atau ke kanan. subjek juga menggambar persegipanjang dengan ukuran yang sesuai dengan luas persegipanjang tersebut serta mentukan perubahan keliling kedua persegipanjang setelah panjang, lebar, dan tinggi diperpanjang dari ukuran semula. Subjek menggambar balok dengan memisalkan ukuran panjang,lebar, dan tinggi yang sesuai dengan volume balok yang ada di soal.. la juga menentukan jumlah panjang semua rusuk balok setelah panjang, lebar, dan tinggi diperpanjang atau diperpendek ukurannya. Namun, SI tidak mendeskripsikan kesamaan kedua ide yang ia temukan. Pada tahap analyze, subjek mengupas kembali langkah-langkah yang telah ia lakukan sebelumnya. Subjek menjelaskan kembali dari awal ia memisalkan ukuran persegipanjang dan balok yang sesuai dengan luas dan volume bangun tersebut. la juga menjelaskan kembali bagaimana ia mendapatkan selisih keliling kedua persegipanjang, perubahan keliling persegipanjang, dan jumlah panjang semua rusuk balok yang 
dia nyatakan dalam bentuk persamaan. Pada tahap transform, subjek dapat menyimpukan dan menafsirkan informasi berdasarkan apa yang telah dikerjakan sebelumnya. Subjek menyimpukan selisih keliling kedua persegipanjang setelah suatu titik pada salah satu sisi persegipanjang digeser ke kiri ataupun ke kanan, perubahan keliling persegipanjang serta jumlah panjang semua rusuk balok setelah ukuran panjang, lebar, dan tinggi balok berubah. Pada tahap experience, subjek menerapkan hasil yang di dapat untuk memecahkan masalah yang dia hadapi. subjek telah menerapkan hasil yang ia dapatkan untuk menyelesaikan masalah yang ia hadapi. Subjek dapat mensubstitusi jarak pergeseran titik B, penambahan ukuran panjang dan lebar, serta besarnya penambahan atau pengurangan ukuran rusuk balok ke persamaan yang dihasilkannya. Sehingga, ia dapat mengetahui selisih keliling kedua persegipanjang, perubahan keliling persegipanjang $A B C D$, dan jumlah panjang semua rusuk balok .

\section{PENUTUP}

\section{Simpulan}

Berdasarkan hasil dan pembahasan di atas, maka dapat disimpulkan bahwa kedua subjek telah melalui tahapan berpikir metaforis. Pada tahap connect, Subjek Reflektif (SR) telah menghubungkan kedua ide yang ia miliki begitu halnya dengan subjek impulsive (SI). Pada tahap relate, SR mengaitkan dengan beberapa topic di matematika seperti aljabar, PLSV, SPLDV, Volume dan keliling sedangkan SI mengaitkannya dengan materi PLSV, Luas dan keliling, serta volume dan luas permukaan. Pada tahap explore, kedua subjek membuat model yang sesuai dengan masalah yang ia hadapi, kedua subjek menjelaskan langkah-langkah dari awal bagaimana ia menemukan selisih keliling kedua persegipanjang setelah titik pada salah satu sisi persegipanjang digeser sesuai kehendaknya, perubahan keliling, serta jumlah panjang semua rusuk balok setlah ukuran rusuk diperpanjang atau diperpendek bedanya SI tidak mendeskripsikan kesaman kedua ide. Pada tahap analyze, kedua subjek menejelaskan kembali mengenai langkah-langkah yang ia lakukan.
Pada tahap transform, kedua subjek menyimpulkan besarnya selisih keliling persegi panjang baik pada saat salah satu titik pada sisi persegipanjang digeser ke kiri atau ke kanan, besarnya perubahan keliling persegipanjang setelah panjang dan lebar diperpanjang, serta jumlah panjang semua rusuk balok setelah panjang, lebar, dan tinggi balok diperpanjang atau diperpendek dari ukuran semula. Ketiga hal tersebut ia nyatakan dalam bentuk persamaan. Sedangkan pada tahap experience, kedua subjek telah menerapkan hasil yang didapat untuk menyelesaikan masalah yang ia hadapi, kedua subjek dapat mensubstitusi jarak pergeseran titik $B$, besarnya penambahan ukuran panjang dan lebar, serta penambahan atau pengurangan ukuran balok pada persamaan yang dihasilkannya.

\section{Saran}

(1) Hasil penelitian ini menunjukkan adanya perbedaan profil berpikir metaforis siswa bergaya kognitif reflektif dan bergaya kognitif impulsif dalam memecahkan masalah pengukuran. Oleh karena itu, sebaiknya hasil penelitian ini dapat dijadikan pandangan atau bahan pertimbangan bagi guru untuk memberikan kesempatan bagi setiap siswa untuk menyelesaikan masalah dengan cara yang mereka miliki dan (2) Hasil penelitian ini masih terbatas pada subjek bergaya kognitif reflektif dan bergaya kognitif impulsif. Padahal dalam berpikir metaforis peneliti menduga masih banyak hal yang ikut mempengaruhinya. Jika pembaca ingin mengadakan penelitian lanjutan, maka untuk memperkaya tujuan, sebaiknya dapat ditinjau dari beberapa hal seperti gaya belajar, gaya kognitif FI-FD atau kemampuan matematika.

\section{DAFTAR PUSTAKA}

Alhaddad, I. (2012). Sejauh Mana Guru Menggunakan Metafora Dalam Kepeduliannya untuk meningkatkan Kemampuan Matematika Siswa. Jurnal Infinity, 1(2), 159-168.

Carreira, S. (2001). Where there's a model, there's a metaphor: Metaphorical thinking in students' understanding of a mathematical model. Mathematical thinking and learning, 3(4), 261-287.

Hendriana, H. (2012). Pembelajaran Matematika Humanis dengan Metaphorical Thinking Untuk Meningkatkan Kepercayaan Diri Siswa. Infinity Journal, 1(1), 90-103. 
Hendriana, Heris. (2015). Kemampuan Metaphorical Thinking Guru Dalam Mengembangkan Pembelajaran Matematika. Makalah disajikan pada Prosiding Seminar Nasional dan Lomba Media Pembelajaran Lubuk Linggau, tanggal 21-22 November 2015

Hendriana, H. dan Soemarmo, U. (2014). Penilaian Pembelajaran Matematika. Bandung: Refika Aditama.

Sanchez-Ruiz, M. J., Santos, M. R., \& Jiménez, J. J. (2013). The role of metaphorical thinking in the creativity of scientific discourse. Creativity Research Journal, 25(4), 361-368.

Lai, M. Y. (2013). Constructing Meanings of Mathematical Registers Using Metaphorical Reasoning and Models. Mathematics Teacher Education and Development, 15(1), 29-47.

Nasution. (2008). Berbagai Pendekatan Dalam Proses Belajar dan Mengajar. Jakarta: Bumi Aksara
Nasution, S. (2012). Kurikulum dan Pengajaran. Bandung: Sinar Grafika Ofset.

NCTM. (2012). Principles and Standards for School Mathematics. Canada.

Sunito, I. (2013). Metaphorming. Jakarta: Indeks.

Susanah. (2014). Geometri. Surabaya: Universitas Negeri Surabaya University Press.

Susanto. (2008). Mahasiswa Field Independent dan Field Dependent Dalam Memahami Konsep Grup *. Artikel disajikan dalam Seminar Matematika dan Pendidikan Matematika tanggal 28 Nopember 2008 di Universitas Negeri Yogyakarta.

Warli. (2010). Profil Kreativitas Siswa yang Bergaya Kognitif Reflektif dam Siswa yang Bergaya Kognitif Impulsif dalam Memecahkan Masalah Geometri. (Disertasi Tidak Dipublikasikan). Universitas Negeri Surabaya.

Yuwono, I. (2010). Pendidikan Matematika 2. Jakarta: Universitas Terbuka 